\title{
Effect Of Nanoparticles Based Root Canal Disinfectants On Enterococcus Faecalis - A Systematic Review
}

\author{
Review Article
}

Kalyani Behera ${ }^{1}$, Iffat $\mathrm{Nasim}^{2 *}$

${ }^{1}$ Department of Conservative Dentistry and Endodontics, Saveetha Dental College, Saveetha Institute of Medical and Technical Sciences, Saveetha University, Chennai- 600077, India.

${ }^{2}$ Professor and Head, Department of Conservative Dentistry and Endodontics, Saveetha Dental College, Saveetha Institute of Medical and Technical Sciences, Saveetha University, Chennai - 600077, India.

\section{Abstract}

\begin{abstract}
Aim: The main goal of endodontic treatment is to prevent and to eliminate endodontic infection and allow healing of apical periodontitis. Bacteria is the main etiological factor in the development of dentinal caries and its progression to pulp and periapical disease.The complexity of the root canal system with its isthmuses, ramifications, and dentinal tubules make complete debridement of bacteria almost impossible by conventional methods and therefore irrigation is performed with the highest technical standards. Enterococcus faecalis is the bacterial species most frequently recovered from the root filled teeth and is highly associated with the endodontic failures and shows resistance to common intracanal medications. The increasing resistance of pathogenic bacteria to antibiotics is challenging which has led to the search for new and more efficient antibacterial agents. Nanotechnology has proven to be an effective tool for the fight against bacteria.

Objective: To evaluate the effect of nanoparticles based root canal disinfectants on Enterococcus faecalis.

Search Strategy: A search was performed in the electronic database (i.e., PUBMED CENTRAL, Medline and Google Search) using search terms alone and in combination by means of PUBMED search builder upto October 2020.

Selection Criteria: Studies were selected if they met the following criteria: In vitro/ In vivo studies, ex vivo, randomized controlled trials and Experimental studies evaluating the reduction of microbial load and biofilm biomass upon using Nanoparticles based root canal disinfectants.

Data Collection and Analysis: All the studies included were based on the data extraction and analysis of the studies for quality and publication bias. The data collection form was customized. The primary outcome measure was to evaluate the microbial load when Nanoparticles based root canal disinfectants were used against Enterococcus faecalis.

Main Results: The results showed that there was a significant difference in the reduction of the microbial load when nanoparticles based root canal disinfectants were used against Enterococcus faecalis.

Conclusion: Based on this review, it may be concluded that nanoparticles based root canal disinfectants can be used in the reduction of the Enterococcus faecalis microbial load.
\end{abstract}

Keywords: Antibacterial; Endodontic Infection; Intracanal Medicaments; Irrigants; Periapical Disease; Nanotechnology.

\section{Introduction}

\section{Background}

The presence of bacteria and their by-products are responsible for various pulpal and periapical diseases. Enterococcus faecalis is the most dominant biofilm forming bacteria found in teeth with periradicular pathologies. It has an intrinsic resistance to irrigant solutions, intracanal medicaments, several antibiotics, and highly alkaline $\mathrm{pH}$. It has the ability to tolerate starvation, harsh environment, and invade deeply into the dentinal tubules. To achieve complete success in root canal treatment, suppression of the biofilm is necessary $[1,2]$. Cleaning and shaping of the root canal along with irrigation protocol have been shown to effectively de-

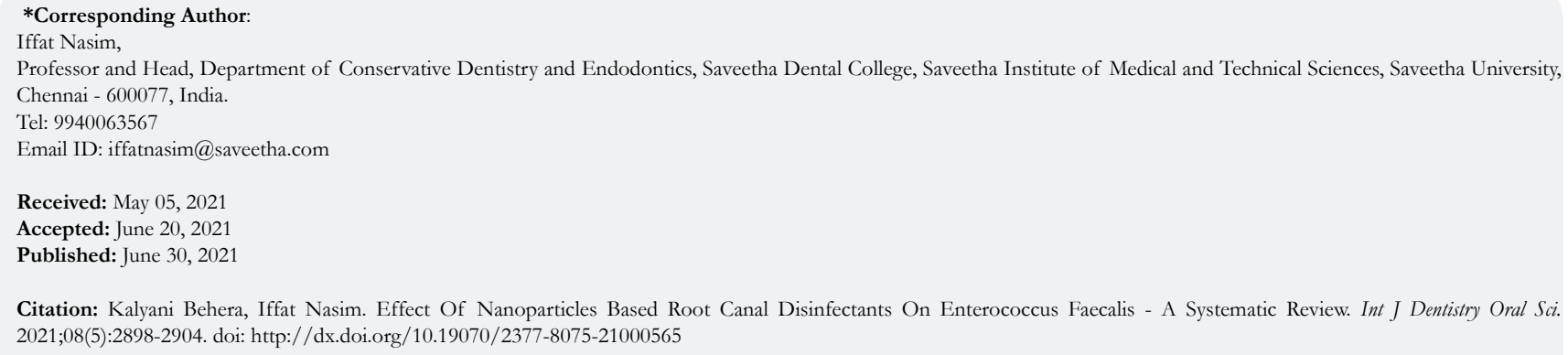

Copyright: Iffat Nasim 2021 . This is an open-access article distributed under the terms of the Creative Commons Attribution License, which permits unrestricted use, distribution and reproduction in any medium, provided the original author and source are credited. 
crease the number of microorganisms in the root canal. However, these procedures are unable to completely eliminate bacteria from lateral canals, isthmuses, and apical deltas. Therefore, the antibacterial protocol is achieved by utilizing intracanal medicaments [3]. Calcium hydroxide and chlorhexidine have been used since long time as effective intracanal medicaments. In endodontics, nanoparticles have been used as irrigants, intracanal medicaments or root canal sealers [4]. Nanoparticles are a class of newer materials which are hypothesized to have antibacterial effects. They cause disruption of the biofilm due to their nano size and structure. The nano size provides increased surface area which can absorb other medicaments and exert antimicrobial effects [5]. Silver nanoparticles are commonly used as they show strong bactericidal potential against Gram - positive, Gram- negative and multidrug- resistant bacteria. Nanoparticles have an ability to interact with bacterial cell wall leading to structural changes and then damaging the tissue protein [5-7]. The advantage of the use of nanotechnology is an increase in the surface- to- volume ratio of the materials, which increases the solubility, chemical activity and antibacterial efficacy of these agents as intracanal medicaments $[3,8]$. Advances in nanotechnology have provided new and promising opportunities to kill bacteria, disrupt biofilm, and control dentinal tubule infection $[9,10]$. A wide range of nanoparticles with antimicrobial activity have been developed in the recent years. Although these NPs are a potentially effective technology for endodontic disinfection, the prolonged contact time required to achieve effective bacterial killing and the toxicity issues in silver NPs impose significant drawbacks. Newer nanoparticles formulations as well as other technologies (such as photodynamic therapy) have been reported to enhance biofilm elimination $[11,12]$. Previously our team has a rich experience in working on various research projects across multiple disciplines [13-27] Now the growing trend in this area motivated us to pursue this project.

The effect of Nanoparticles based root canal disinfectants on Enterococcus faecalis is evaluated in the current systematic review.

\section{Structured Question}

Does Nanoparticle based root canal disinfectants have any effect on the reduction of Enterococcus faecalis in the root canal system?

\section{PICOS Analysis}

Population- Inoculated root canals, Extracted teeth with microbial species, Cell culture plates

Intervention- Nanoparticles based root canal disinfectants (Irrigants / Intracanal Medicaments)

Comparison- Treatment with commonly used irrigants/ intracanal medicaments

Outcome- Eradication of Enterococcus faecalis bacterial load

Study Design- All experimental studies, randomized controlled studies, In vitro, In vivo and ex-vivo studies

\section{Null Hypothesis}

There is no significant difference in the reduction of Enterococ- cus faecalis in the root canal system between nanoparticles based root canal disinfectants and other antimicrobial agents.

\section{Alternate Hypothesis}

There is a significant difference in the reduction of Enterococcus faecalis in the root canal system between nanoparticles based root canal disinfectants and other antimicrobial agents.

\section{Materials And Methods}

\section{Sources Used}

For identification of studies included or considered for this review, detailed search strategies were developed for the database searched. The MEDLINE search used the combination of controlled vocabulary and free text terms.

\section{Searched Databases:}

\section{PUBMED}

PUBMED Advanced Search

SCIENCE DIRECT

Cochrane Database of Systematic Review

Google Scholar

\section{Language}

There were no language restrictions

\section{Hand Search}

The following journals were hand searched:-

Journal of Research in Medical and Dental Science

Journal of Nanomaterials

Journal of Conservative Dentistry

Iranian Endodontic Journal

Indian Journal of Dental Research

\section{Inclusion Criteria}

Criteria For Considering Studies In This Review:-

In vitro studies assessing the efficacy of nanoparticles based root canal disinfectants against Enterococcus faecalis.

In vivo studies assessing the efficacy of nanoparticles based root canal disinfectants on reduction of Enterococcus faecalis.

Studies evaluating elimination or reduction of bacteria from root canal system.

Randomized controlled studies

\section{Exclusion Criteria}

The Following Studies Were Excluded:-

Studies evaluating the effect of nanoparticles in bovine \& animal studies. 
Studies in which comparison between nanoparticle based root canal disinfectant \& commonly used disinfectant was not done. Studies in which reduction in Enterococcus faecalis microbial load was not evaluated.

\section{Characteristics Of Excluded Studies}

A total of 439 studies were excluded from the electronic search owing to the irrelevance. Animal studies and the studies that showed the effect of nanoparticles based root canal disinfectants against oral microorganisms other than oral origin were excluded. A total of 9 articles have been included [Table 2].

\section{Results}

\section{Description of Studies}

The search identified 448 publications out of which 437 were excluded after reviewing the title/ abstract and 2 were excluded after reviewing the full articles. A total of 9 publications that fulfilled all criteria for inclusion were selected.

\section{Quality Assessment}

The quality assessment of included trials was undertaken independently as a part of the data extraction process. Four main quality criteria were examined:

\section{Method of Randomization, recorded as}

a. Yes - Adequate as described in the text

b. No - Inadequate as described in the text

c. Unclear in the text

\section{Allocation Concealment, recorded as}

a. Yes - Adequate as described in the text

b. No - Inadequate as described in the text

c. Unclear in the text

3. Outcome assessors blinded to intervention, recorded as

a. Yes - Adequate as described in the text

b. No - Inadequate as described in the text

c. Unclear in the text

4. Completeness of follow- up (was there a clear explanation for withdrawals and dropouts in each treatment group) assessed as: a. Yes - Dropouts were explained

b. No - Dropouts were not explained

c. None- No dropouts or withdrawals

Other methodological criteria examined included:

1. Presence or absence of sample size calculation

2. Comparability of groups at the start

3. Clear inclusion/ exclusion criteria

Presence/absence of estimate of measurement error. The validity and reproducibility of the method of assessment.

\section{Risk of Bias in Included Studies}

The assessments for the four main methodological quality items are shown in table. The study was assessed to have a "High risk" of bias if it did not record a "Yes" in three or more of the four main categories," Moderate "if two out of four categories did not record a "Yes", and "Low" if randomization assessor blinding and completeness of follow - up were considered adequate.

\section{Discussion}

\section{Interpretation Of Results}

The purpose of this systematic review was to evaluate the efficacy of nanoparticles based root canal disinfectants against Enterococcus faecalis. Eleven in vitro studies fulfilled the criteria for being included in this review.

No in vivo studies are reported in the literature. Thus, this Systematic Review reported only in- vitro studies.

[28] conducted a study where they evaluated antimicrobial efficacy of silver $(\mathrm{Ag} \mathrm{Np})$ and gold nanoparticles $(\mathrm{Au} \mathrm{Np})$ with and without Nd: YAG laser ( $\mathrm{L}$ ) irradiation against inoculated enterococcus faecalis in infected human root dentin. The result has shown that the application of Nd:YAG laser in combination with silver nanoparticles irrigation had shown significant effects in the reduction of microbial colonies of enterococcus faecalis when compared to other groups. There was no significant difference between $\mathrm{Au}+\mathrm{Nd}$ : YAG laser \& CHX.

[29] conducted a study to evaluate the efficacy of nanosilver (NS) solution as an endodontic irrigation solution of primary teeth against enterococcus faecalis with colony forming unit test and

Table 1. Representing the Variables Of Interest.

\begin{tabular}{|c|c|}
\hline S.No & Variables of Interest \\
\hline 1 & Elimination of bacteria from the root canal system \\
\hline 2 & Reduction in the microbial load \\
\hline
\end{tabular}

Table 2. Representing the characteristics of excluded studies.

\begin{tabular}{|c|c|c|c|}
\hline S.No & Author & Year & Reason For Exclusion \\
\hline 1 & PE Das et al & 2020 & No comparison was done with other disinfectant \\
\hline 2 & Alzahrani et al & 2018 & No comparison was done with other disinfectant \\
\hline
\end{tabular}


Table 3. Representing the General Information And Results Of The Included Articles.

\begin{tabular}{|c|c|c|c|c|c|c|c|}
\hline S. No & Author & $\begin{array}{c}\text { Study } \\
\text { Design }\end{array}$ & Sample size & Antimicrobial agent used & $\begin{array}{l}\text { Method of } \\
\text { evaluation }\end{array}$ & $\begin{array}{l}\text { Statistical } \\
\text { analysis }\end{array}$ & Interpretation \\
\hline 1 & $\begin{array}{c}\text { Kushwaha V } \\
\text { et al, } 2018\end{array}$ & In vitro & $\mathrm{n}=120$ & $\begin{array}{l}\text { 1. Group I - ( Negative control group ) } \\
\mathrm{n}=20 \text { [ } 3 \mathrm{ml} \text { normal saline] } \\
\text { 2. Group II- }(2 \% \mathrm{CHX}) \mathrm{n}=20 \\
\text { 3. Group III- } 3 \mathrm{ml} \text { of SNP solution } \\
\mathrm{n}=20 \\
\text { 4. Group IV- } 3 \mathrm{ml} \text { of GNP solution } \\
\mathrm{n}=20 \\
\text { 5. Group V- ( } \mathrm{SNP}+\mathrm{Nd} \text { : YAG lasers) } \\
\mathrm{n}=20 \\
\text { 6. Group VI- }(\mathrm{GNP}+\mathrm{Nd} \text { : YAG Lasers } \\
\mathrm{n}=20\end{array}$ & $\mathrm{CFU} / \mathrm{ml}$ & $\begin{array}{l}\text { One way } \\
\text { ANOVA } \\
\text { Tukey's Post } \\
\text { hoc test }\end{array}$ & $\begin{array}{c}\text { AgNPs \& Nd:YAG lasers resulted } \\
\text { in significant reduction in micro- } \\
\text { bial load when compared to other } \\
\text { disinfectants. } \\
\text { Au+Nd:YAG laser \& CHX } \\
\text { showed similar effect. }\end{array}$ \\
\hline 2 & $\begin{array}{l}\text { Moradi \& } \\
\text { Haghgoo } \\
\text { et al, } 2018\end{array}$ & Ex-Vivo & $\mathrm{n}=30$ & $\begin{array}{l}\text { 1. Group A- Nanosilver particles ( } \\
\qquad \mathrm{n}=10) \\
\text { 2. Group B- } 2.5 \% \text { Naocl }(\mathrm{n}=10) \\
\text { 3. Group C- Saline }(\mathrm{n}=10)\end{array}$ & $\mathrm{CFU} / \mathrm{ml}$ & $\begin{array}{c}\text { Kolmogorov- } \\
\text { smirnov, Welch } \\
\text { Dunnett's, T3 } \\
\text { test }\end{array}$ & $\begin{array}{l}\text { Sodium hypochlorite showed the } \\
\text { highest antimicrobial effective- } \\
\text { ness against E. faecalis \& showed } \\
\text { significant differences. NS solution } \\
\text { can also be used as an alternative } \\
\text { root canal irrigant as it showed } \\
\text { antibacterial activity. }\end{array}$ \\
\hline 3 & $\begin{array}{l}\text { Bukhari } \\
\text { et al,2018 }\end{array}$ & $\begin{array}{l}\text { In vitro } \\
\text { study }\end{array}$ & $\begin{array}{l}\text { Extracted teeth } \\
\text { with microbial } \\
\text { species } \\
\text { Sample size not } \\
\text { mentioned }\end{array}$ & $\begin{array}{c}\text { Group 1- PBS } \\
\text { ( negative control) } \\
\text { Group 2- 3\% H2O2 } \\
\text { Group 3- Io- } \mathrm{Np}(0.5 \mathrm{mg} / \mathrm{ml}) \\
\text { Group 4- Io-Np }(0.5 \mathrm{mg} / \mathrm{ml}) \pm 3 \% \\
\mathrm{H} 2 \mathrm{O} 2 \\
\text { Group 5- 3\% NaOcl } \\
\text { Group 6- 2\% CHX }\end{array}$ & $\begin{array}{l}\text { SEM coupled } \\
\text { energy with } \\
\text { dispersive spec- } \\
\text { troscopy Confocal } \\
\text { laser scanning } \\
\text { microscopy }\end{array}$ & $\begin{array}{l}\text { 2- tailed un- } \\
\text { paired t test } \\
\text { - }\end{array}$ & $\begin{array}{c}\text { IO-Np's/ H2O2 was significantly } \\
\text { better \& shows better antibacterial } \\
\text { activity when compare to conven- } \\
\text { tional irrigants. }\end{array}$ \\
\hline 4 & $\begin{array}{l}\text { Pagonis } \\
\text { et al,2010 }\end{array}$ & $\begin{array}{l}\text { In vitro } \\
\text { Study }\end{array}$ & $\mathrm{n}=32$ & $\begin{array}{c}\text { Group 1- No light/no MB nanoparticle } \\
\text { ( control) } \\
\text { Group 2- MB-loaded nanoparticles } \\
\text { Group 3- Light and MB-loaded nano- } \\
\text { particle.. }\end{array}$ & $\mathrm{CFU}$ & $\begin{array}{l}\text { Two way analy- } \\
\text { sis of variance }\end{array}$ & $\begin{array}{l}\text { MB- loaded nanoparticles may be } \\
\text { used as an adjunct in endodontic } \\
\text { treatment. }\end{array}$ \\
\hline 5 & $\begin{array}{l}\text { Aseel Haidar } \\
\text { MJ et al,2019 }\end{array}$ & $\begin{array}{l}\text { In Vitro } \\
\text { Study }\end{array}$ & $\mathrm{n}=55$ & $\begin{array}{c}\text { Group I- } 100 \text { ppm silver nanoparti- } \\
\text { cles }=15 \\
\text { Group II- } 2.5 \text { sodium hypochlorite }=15 \\
\text { Group III- } 2 \% \\
\text { Chlorhexidinen }=15 \\
\text { Group IV }- \text { Normal saline } \mathrm{n}=10 \\
\text { (control group ) }\end{array}$ & $\mathrm{CFU} / \mathrm{ml}$ & $\begin{array}{l}\text { Shapiro -Wilk } \\
\text { test, One -way } \\
\text { ANOVA \& } \\
\text { Games- Howell } \\
\text { test }\end{array}$ & $\begin{array}{l}\mathrm{Ag} \mathrm{NPs} \text { proved to be as effective } \\
\text { as } \mathrm{NaOCl} \& \mathrm{CHX} \text { in terms of } \\
\text { antibacterial action. }\end{array}$ \\
\hline 6 & $\begin{array}{l}\text { Pedro IV } \\
\text { Gonzalez } \\
\text { Luna et al, } \\
2016\end{array}$ & $\begin{array}{c}\text { An Ex Vivo } \\
\text { Study }\end{array}$ & $\mathrm{n}=120$ & $\begin{array}{l}\text { Group } \mathrm{A}-\mathrm{n}=30 \text {, teeth irrigated with } \\
\text { a dispersion of silver of silver nano- } \\
\text { particle } \\
\text { Group B- } \mathrm{n}=30 \text {, teeth irrigated with a } \\
\text { sodium hypochlorite solution }(2.25 \%) \\
\text { Group C- } \mathrm{n}=30 \text {, teeth irrigated with a } \\
\text { dispersion of silver nanoparticles } \\
\quad+\text { EDTA }(17 \%) \\
\text { Group D-30 teeth with a saline solution }\end{array}$ & $\begin{array}{l}\text { Spectrophoto- } \\
\text { meter by measur- } \\
\text { ing turbidity }\end{array}$ & $\begin{array}{l}\text { One way } \\
\text { ANOVA }\end{array}$ & $\begin{array}{l}\text { There was no significant difference } \\
\text { between the bactericidal effect of } \\
\text { AgNps \& } 2.25 \% \mathrm{NaOCl} \text {. }\end{array}$ \\
\hline 7 & $\begin{array}{l}\text { Jhamb et al, } \\
2020\end{array}$ & $\begin{array}{l}\text { In Vitro } \\
\text { Study }\end{array}$ & $\begin{array}{l}\text { Culture plates } \\
\text { were used }\end{array}$ & $\begin{array}{c}\text { Group I- Silver Nanocure gel, } \\
\text { Group 2- Silver Nanocure gel +Cavis- } \\
\text { pet gel( 1:1) } \\
\text { Group 3- Silver Nanocure gel + Aveu - } \\
\text { Cal gel( 1:1) } \\
\text { Group 4- Silver Nanocure gel + Cavis- } \\
\text { pet gel + Aveu- cal gel( 1:1:1) } \\
\end{array}$ & $\begin{array}{l}\text { Agar diffusion } \\
\text { test }\end{array}$ & Student t- tests & $\begin{array}{c}\text { When silver nanoparticles were } \\
\text { combined with } \mathrm{CaOH} \& \mathrm{CHX} \\
\text {, the antibacterial activity was } \\
\text { enhanced. }\end{array}$ \\
\hline 8 & $\begin{array}{c}\text { Samiei et al, } \\
2018\end{array}$ & $\begin{array}{l}\text { In vitro } \\
\text { study }\end{array}$ & $\mathrm{n}=132$ & $\begin{array}{c}\text { Group 1- Calcium hydroxide with } \\
0.12 \% \text { CHX paste } \\
\text { Group 2- Zinc oxide nanoparticles gel } \\
\text { Group 3- Zinc oxide/ silver nanopar- } \\
\text { ticle gel } \\
\text { Group 4- Normal saline } \\
\text { (control group) } \\
\end{array}$ & $\mathrm{CFU} / \mathrm{ml}$ & $\begin{array}{l}\text { One Way } \\
\text { ANOVA }\end{array}$ & $\begin{array}{l}\text { The mixture of calcium hydrox- } \\
\text { ide/ chlorhexidine was effective } \\
\text { against E.faecalis \& show better } \\
\text { antibacterial effect as compared to } \\
\text { other groups. Addition of silver } \\
\text { nanoparticles to ZnO did not } \\
\text { reduce the bacterial count. }\end{array}$ \\
\hline 9 & $\begin{array}{c}\text { De Almeida } \\
\text { et al, } 2018\end{array}$ & $\begin{array}{l}\text { In Vitro } \\
\text { Study }\end{array}$ & $\mathrm{n}=72$ & $\begin{array}{c}\text { Group } 1-0.85 \% \text { saline } \mathrm{n}=12 \\
\text { Group 2- } 2 \% \text { Chlorhexidine gluconate } \\
(\mathrm{CHX}) \mathrm{n}=12 \\
\text { Group 3- } 5 \% \text { sodium hypochlorite } \\
\mathrm{NaOCl}) \mathrm{n}=12 \\
\text { Group } 4-1 \% \mathrm{NaOCl} n=12 \\
\text { Group } 5-1 \% \text { silver nanoparticle solu- } \\
\text { tion } \mathrm{n}=12 \\
\text { Group 6- } 26 \% \mathrm{ZnO} \text { Np solution } \mathrm{n}=12\end{array}$ & $\begin{array}{c}\mathrm{CFU} / \mathrm{ml} \\
\mathrm{SEM}\end{array}$ & $\begin{array}{l}\text { Kruskal-Wallis } \\
\text { \& Dunn post } \\
\text { hoc tests }\end{array}$ & $\begin{array}{c}\text { Silver nanoparticles \& Zinc oxide } \\
\text { nanoparticles were as effective as } \\
\text { conventional irrigants in terms of } \\
\text { antimicrobial activity. }\end{array}$ \\
\hline
\end{tabular}


Table 4. Representing the RISK OF BIAS - MAJOR CRITERIA.

\begin{tabular}{|c|c|c|c|c|c|}
\hline \multirow{2}{*}{ S.No } & Study & \multirow{2}{*}{$\begin{array}{c}\text { Randomi- } \\
\text { zation }\end{array}$} & Allocation & Assessor & Dropouts \\
\cline { 5 - 6 } & & Concealment & Blinding & Described \\
\hline 1 & Kushwaha V et al 2018 & No & No & No & No \\
\hline 2 & Moradit \& Haghgoo et al 2018 & No & No & No & No \\
\hline 3 & Bukhari et al 2018 & No & No & No & No \\
\hline 4 & Pagonis et al 2010 & No & No & No & No \\
\hline \multirow{2}{*nnnnn}{5} & Aseel Haidar MJ & No & No & No & \multirow{2}{*}{ No } \\
& AL - Haidar et al, 2019 & & No & No & No \\
\hline 6 & Pedro IV Gonzalez Luna et al, 2016 & No & No & No & No \\
\hline 7 & Jhamb et al, 2020 & No & No & No & No \\
\hline 8 & Samiei et al, 2018 & No & No & No & No \\
\hline 9 & De Almeida et al, 2018 & &
\end{tabular}

Table 5. Representing the RISK OF BIAS - MINOR CRITERIA.

\begin{tabular}{|c|c|c|c|c|c|}
\hline \multirow{2}{*}{ S.No } & \multirow{2}{*}{ Study } & Sample & Baseline & \multirow{2}{*}{$\begin{array}{c}\text { I/E Cri- } \\
\text { teria }\end{array}$} & \multirow{2}{*}{$\begin{array}{c}\text { Method } \\
\text { Error }\end{array}$} \\
\hline & & justified & Comparison & & \\
\hline 1 & Kushwaha V et al 2018 & Yes & Yes & Yes & No \\
\hline 2 & Moradit \& Haghgoo et al 2018 & Yes & Yes & Yes & No \\
\hline 3 & Bukhari et al 2018 & Yes & Yes & Yes & No \\
\hline 4 & Pagonis et al 2010 & Yes & Yes & Yes & No \\
\hline \multirow{2}{*}{5} & Aseel Haidar MJ & \multirow{2}{*}{ Yes } & \multirow{2}{*}{ Yes } & \multirow{2}{*}{ Yes } & \multirow{2}{*}{ No } \\
\hline & AL - Haidar et al, 2019 & & & & \\
\hline 6 & Pedro IV Gonzalez Luna et al, 2016 & Yes & Yes & Yes & $\mathrm{No}$ \\
\hline 7 & Jhamb et al, 2020 & Yes & Yes & Yes & No \\
\hline 8 & Samiei et al, 2018 & Yes & Yes & Yes & No \\
\hline 9 & De Almeida et al, 2018 & Yes & Yes & Yes & No \\
\hline
\end{tabular}

Figure 1. Representing the Search Flow chart.

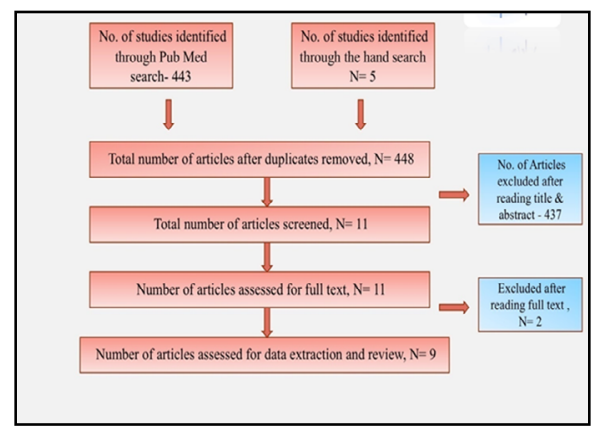

found that the sodium hypochlorite showed the highest antimicrobial effectiveness against E. faecalis when compared with normal saline and NS solution.

[30], tested the efficacy of iron oxide nanoparticles against E. faecalis and compared with $3 \% \mathrm{H}_{2} \mathrm{O}_{2}$, Io-Np's, Io-Np's $+3 \% \mathrm{H}_{2} \mathrm{O}_{2}$, $3 \% \mathrm{NaOCl}$ and $2 \% \mathrm{CHX}$. It has shown that the IO-NP's/ $\mathrm{H}_{2} \mathrm{O}_{2}$ was significantly better $\&$ shows better antibacterial activity when compared to conventional irrigants.

In a study conducted by [31] used MB- loaded PLGA (Poly lacticco-glycolic acid) nanoparticles for evaluation of in vitro against $\mathrm{E}$. faecalis. It has also shown that the photodynamic effects of the nanoparticles play an important role against E. faecalis. Hence, concluded that the utilization of PLGA nanoparticles with photodynamic therapy can be used as an adjunct in antimicrobial endodontic treatment.

Aseel Haidar MJ AL- Haidar conducted a study wherein he investigated the antibacterial effect of silver nanoparticles, sodium hypochlorite \& chlorhexidine in reducing the bacterial infection of the root canals by colony forming unit. AgNP's proved to be as effective as $\mathrm{NaOCl} \& \mathrm{CHX}$ in terms of antibacterial action.

[32] conducted a study to determine the bactericidal effect of silver nanoparticles as a final irrigation used in endodontics when compared with the sodium hypochlorite solution, silver nanoparticles + EDTA and saline solution.Silver nanoparticles as an en- 
dodontic irrigant can be used against E.faecalis as it shows same effect with $2.25 \% \mathrm{NaOCl}$.

In a study conducted by [33] he compared the antibacterial effects of silver nanoparticle gel alone $\&$ in combination of silver nanoparticle gel with various medicaments by using agar diffusion test. It has found that when silver nanoparticles were combined with $\mathrm{CaOH} \& \mathrm{CHX}$, the antibacterial activity was enhanced.

[34], compared the antibacterial effects of two gels containing Zinc oxide \& Zinc oxide ( Silver nanoparticles \& a mixture of calcium hydroxide , $0.12 \% \mathrm{CHX}$ as an intracanal medicament in root canals which was contaminated with E. faecalis. It has shown that the mixture of calcium hydroxide / CHX was effective against E.faecalis \&show better antibacterial effect as compared to other groups. Addition of silver nanoparticles to $\mathrm{ZnO}$ did not reduce the bacterial count.

[35] compared the efficacy of silver \& zinc oxide nanoparticles with conventional endodontic irrigants against $\mathrm{E}$. faecalis biofilm in root canals tested by using colony forming unit analysis \& SEM and found that the $1 \% \mathrm{AgNp}+26 \% \mathrm{ZnO}$ nanoparticles were as effective as conventional endodontic irrigants against $\mathrm{E}$. faecalis. Our institution is passionate about high quality evidence based research and has excelled in various fields [17, 36-45].

Out of 11 studies included in this systematic review, 4 studies showed that nanoparticles based disinfectants were better in eradicating Enterococcus faecalis as compared to the commonly used disinfectants. 1 study showed that there is no significant difference between nanoparticle based disinfectant and commonly used disinfectants. 4 studies showed that the combination of nanoparticles with other agents was effective and showed a significant difference. Studies by Samiei et.al, Moradi \& Haghgoo et.al showed that commonly used disinfectants were better than the nanoparticles.

\section{Meta- analysis}

Mostly systematic reviews will perform meta analysis, which involves the statistical pooling of data from individual studies when the studies are similar. A meta - analysis can yield a more precise overall estimate of the treatment effect. However, meta- analysis may not be appropriate in many situations. Owing to the heterogeneity among the studies, we could not perform a meta- analysis to summarize the data of included articles. Hence, only descriptive evaluation of data has been provided.

\section{Quality of Evidence}

All the studies included in this review have a level of evidence 5 . All are in vitro studies, thus the level of evidence is low.

\section{Implications for practice}

Nanoparticles based root canal disinfectants can be used as an antimicrobial agent either solely or in combination with other disinfectants for root canal treatment.

\section{Implications for Research}

In future, research should be aimed at utilizing this nanoparticles based root canal disinfectants in animal and human populations to exert its associations with other products.

\section{Conclusion}

Nanoparticles based root canal disinfectants can be considered as an alternative disinfectant or can be combined with other disinfectants to exert antimicrobial effect. However, no clinical trials exist on the topic; randomized controlled trials need to be performed to extrapolate the results to the clinical scenario.

\section{Acknowledgement And Declarations}

The authors would like to acknowledge the institution and all the staff members of the Department of Conservative Dentistry and Endodontics for their support towards completion of this research. The authors deny any conflicts of interest associated with this paper.

\section{References}

[1]. Madhubala MM, Srinivasan N, Ahamed S (2011) Comparative evaluation of propolis and triantibiotic mixture as an intracanal medicament against Enterococcus faecalis. J Endod 37:1287-1289

[2]. Sabrah AHA, Yassen GH, Gregory RL (2013) Effectiveness of antibiotic medicaments against biofilm formation of Enterococcus faecalis and Porphyromonas gingivalis. J Endod 39:1385-1389

[3]. Gomes BPFA, Gomes BPF, Ferraz CCR, Vianna ME, Berber VB, Teixeira FB, Souza-Filho FJ (2001) In vitro antimicrobial activity of several concentrations of sodium hypochlorite and chlorhexidine gluconate in the elimination of Enterococcus faecalis. International Endodontic Journal 34:424-428

[4]. Martínez-Castañón GA, Niño-Martínez N, Martínez-Gutierrez F, Martínez-Mendoza JR, Ruiz F (2008) Synthesis and antibacterial activity of silver nanoparticles with different sizes. Journal of Nanoparticle Research 10:1343-1348

[5]. Cheng Z, Al Zaki A, Hui JZ, Muzykantov VR, Tsourkas A (2012) Multifunctional nanoparticles: cost versus benefit of adding targeting and imaging capabilities. Science 338:903-910

[6]. Ayala-Núńez NV, Lara Villegas HH, del Carmen Ixtepan Turrent L, Padilla CR (2009) Silver Nanoparticles Toxicity and Bactericidal Effect Against Methicillin-Resistant Staphylococcus aureus: Nanoscale Does Matter. NanoBiotechnology 5:2-9

[7]. Afkhami F, Pourhashemi SJ, Sadegh M, Salehi Y, Fard MJK (2015) Antibiofilm efficacy of silver nanoparticles as a vehicle for calcium hydroxide medicament against Enterococcus faecalis. Journal of Dentistry 43:1573-1579

[8]. Hernández-Sierra JF, Ruiz F, Pena DCC, Martínez-Gutiérrez F, Martínez AE, de Jesús Pozos Guillén A, Tapia-Pérez H, Castañón GM (2008) The antimicrobial sensitivity of Streptococcus mutans to nanoparticles of silver, zinc oxide, and gold. Nanomedicine: Nanotechnology, Biology and Medicine 4:237-240

[9]. Samiei M, Farjami A, Dizaj SM, Lotfipour F (2016) Nanoparticles for antimicrobial purposes in Endodontics: A systematic review of in vitro studies. Mater Sci Eng C Mater Biol Appl 58:1269-1278

[10]. 10. Ercan E, Ozekinci T, Atakul F, Gül K (2004) Antibacterial activity of $2 \%$ chlorhexidine gluconate and $5.25 \%$ sodium hypochlorite in infected root canal: in vivo study. J Endod 30:84-87

[11]. Shrestha A, Kishen A (2016) Antibacterial Nanoparticles in Endodontics: A Review. J Endod 42:1417-1426

[12]. Pan C-H, Liu W-T, Bien M-Y, Lin I-C, Hsiao T-C, Ma C-M, Lai C-H, Chen M-C, Chuang K-J, Chuang H-C (2014) Effects of size and surface of zinc oxide and aluminum-doped zinc oxide nanoparticles on cell viability inferred by proteomic analyses. Int J Nanomedicine 9:3631-3643

[13]. Govindaraju L, Gurunathan D (2017) Effectiveness of Chewable Tooth Brush in Children-A Prospective Clinical Study. J Clin Diagn Res 11:ZC31-ZC34

[14]. Christabel A, Anantanarayanan P, Subash P, Soh CL, Ramanathan M, Muthusekhar MR, Narayanan V (2016) Comparison of pterygomaxillary dysjunction with tuberosity separation in isolated Le Fort I osteotomies: a prospective, multi-centre, triple-blind, randomized controlled trial. Int J Oral Maxillofac Surg 45:180-185

[15]. Soh CL, Narayanan V (2013) Quality of life assessment in patients with 
dentofacial deformity undergoing orthognathic surgery--a systematic review. Int J Oral Maxillofac Surg 42:974-980

[16]. Mehta M, Deeksha, Tewari D, et al (2019) Oligonucleotide therapy: An emerging focus area for drug delivery in chronic inflammatory respiratory diseases. Chem Biol Interact 308:206-215

[17]. Ezhilarasan D, Apoorva VS, Ashok Vardhan N (2019) Syzygium cumini extract induced reactive oxygen species-mediated apoptosis in human oral squamous carcinoma cells. J Oral Pathol Med 48:115-121

[18]. Campeau PM, Kasperaviciute D, Lu JT, et al (2014) The genetic basis of DOORS syndrome: an exome-sequencing study. Lancet Neurol 13:44-58

[19]. Kumar S, S S (2016) Knowledge and awareness regarding antibiotic prophylaxis for infective endocarditis among undergraduate dental students. Asian J Pharm Clin Res 154

[20]. Christabel SL (2015) Prevalence of type of Frenal Attachment and morphology of frenum in children, Chennai, Tamil Nadu. World J Dent 6:203-207

[21]. Kumar S, Rahman R (2017) Knowledge, awareness, and practices regarding biomedical waste management among undergraduate dental students. Asian J Pharm Clin Res 10:341

[22]. Sridharan G, Ramani P, Patankar S (2017) Serum metabolomics in oral leukoplakia and oral squamous cell carcinoma. J Cancer Res Ther 13:556-561

[23]. Ramesh A, Varghese SS, Doraiswamy JN, Malaiappan S (2016) Herbs as an antioxidant arsenal for periodontal diseases. J Intercult Ethnopharmacol 5:92-96

[24]. Thamaraiselvan M, Elavarasu S, Thangakumaran S, Gadagi JS, Arthie T (2015) Comparative clinical evaluation of coronally advanced flap with or without platelet rich fibrin membrane in the treatment of isolated gingival recession. J Indian Soc Periodontol 19:66-71

[25]. Thangaraj SV, Shyamsundar V, Krishnamurthy A, Ramani P, Ganesan K, Muthuswami M, Ramshankar V (2016) Molecular Portrait of Oral Tongue Squamous Cell Carcinoma Shown by Integrative Meta-Analysis of Expression Profiles with Validations. PLoS One 11:e0156582

[26]. Ponnulakshmi R, Shyamaladevi B, Vijayalakshmi P, Selvaraj J (2019) In silico and in vivo analysis to identify the antidiabetic activity of beta sitosterol in adipose tissue of high fat diet and sucrose induced type-2 diabetic experimental rats. Toxicol Mech Methods 29:276-290

[27]. (2018) Fluoride, fluoridated toothpaste efficacy and its safety in children - review. Int J Pharm Res. https://doi.org/10.31838/ijpr/2018.10.04.017

[28]. Kushwaha V, Yadav R-K, Tikku A-P, Chandra A, Verma P, Gupta P, Shakya V-K (2018) Comparative evaluation of antibacterial effect of nanoparticles and lasers against Endodontic Microbiota: An in vitro study. J Clin Exp Dent 10:e1155-e1160

[29]. Moradi F, Haghgoo R (2018) Evaluation of Antimicrobial Efficacy of Nanosilver Solution, Sodium Hypochlorite and Normal Saline in Root Canal Irrigation of Primary Teeth. Contemp Clin Dent 9:S227-S232

[30]. Bukhari S, Kim D, Liu Y, Karabucak B, Koo H (2018) Novel Endodontic Disinfection Approach Using Catalytic Nanoparticles. J Endod 44:806-812

[31]. Pagonis TC, Chen J, Fontana CR, et al (2010) Nanoparticle-based endodontic antimicrobial photodynamic therapy. J Endod 36:322-328

[32]. González-Luna P-I, Martínez-Castañón G-A, Zavala-Alonso N-V, Patiño-
Marin N, Niño-Martínez N, Morán-Martínez J, Ramírez-González J-H (2016) Bactericide Effect of Silver Nanoparticles as a Final Irrigation Agent in Endodontics onEnterococcus faecalis: AnEx VivoStudy. Journal of $\mathrm{Na}$ nomaterials 2016:1-7

[33]. Jhamb S, Singla R, Kaur A, Sharma J, Bhushan J (2019) An in vitro determination of antibacterial effect of silver nanoparticles gel as an intracanal medicament in combination with other medicaments against Enterococcus fecalis. Journal of Conservative Dentistry 22:479

[34]. Samiei M, Torab A, Hosseini O, Abbasi T, Abdollahi AA, Divband B (2018) Antibacterial Effect of Two Nano Zinc Oxide Gel Preparations Compared to Calcium Hydroxide and Chlorhexidine Mixture. Iran Endod J 13:305-311

[35]. Almeida J de, de Almeida J, Cechella B, Bernardi A, de Lima Pimenta A, Felippe W (2018) Effectiveness of nanoparticles solutions and conventional endodontic irrigants against Enterococcus faecalis biofilm. Indian Journal of Dental Research 29:347

[36]. Vijayashree Priyadharsini J (2019) In silico validation of the non-antibiotic drugs acetaminophen and ibuprofen as antibacterial agents against red complex pathogens. J Periodontol 90:1441-1448

[37]. Pc J, Marimuthu T, Devadoss P (2018) Prevalence and measurement of anterior loop of the mandibular canal using CBCT: A cross sectional study. Clin. Implant Dent. Relat. Res.

[38]. Ramesh A, Varghese S, Jayakumar ND, Malaiappan S (2018) Comparative estimation of sulfiredoxin levels between chronic periodontitis and healthy patients - A case-control study. J Periodontol 89:1241-1248

[39]. Ramadurai N, Gurunathan D, Samuel AV, Subramanian E, Rodrigues SJL (2019) Effectiveness of 2\% Articaine as an anesthetic agent in children: randomized controlled trial. Clin Oral Investig 23:3543-3550

[40]. Sridharan G, Ramani P, Patankar S, Vijayaraghavan R (2019) Evaluation of salivary metabolomics in oral leukoplakia and oral squamous cell carcinoma. J Oral Pathol Med 48:299-306

[41]. Mathew MG, Samuel SR, Soni AJ, Roopa KB (2020) Evaluation of adhesion of Streptococcus mutans, plaque accumulation on zirconia and stainless steel crowns, and surrounding gingival inflammation in primary molars: Randomized controlled trial. Clin Oral Investig 1-6

[42]. Samuel SR (2021) Can 5-year-olds sensibly self-report the impact of developmental enamel defects on their quality of life? Int J Paediatr Dent 31:285-286

[43]. R H, Hannah R, Ramani P, Ramanathan A, R JM, Gheena S, Ramasubramanian A, Monika K (2020) CYP2 C9 polymorphism among patients with oral squamous cell carcinoma and its role in altering the metabolism of benzo[a]pyrene. Oral Surgery, Oral Medicine, Oral Pathology and Oral Radiology 130:306-312

[44]. Chandrasekar R, Chandrasekhar S, Sundari KKS, Ravi P (2020) Development and validation of a formula for objective assessment of cervical vertebral bone age. Prog Orthod 21:38

[45]. Vijayashree Priyadharsini J, Smiline Girija AS, Paramasivam A (2018) In silico analysis of virulence genes in an emerging dental pathogen A. baumannii and related species. Arch Oral Biol 94:93-98. 